\title{
The Causal Relationship Between Unemployment Rate and Underground Economy in Iran
}

\author{
Khossrow Piraee, Hossinali Rajaee* \\ Department of Managment and Economics, Shiraz, University of Islamic Azad, Pardis, Sihiraz, Iran
}

Email address:

kh.piraee@gmail.com (K. Piraee), h.raja.gor@gmail.com (H. Rajaee)

To cite this article:

Khossrow Piraee, Hossinali Rajaee. The Causal Relationship Between Unemployment Rate and Underground Economy in Iran. International Journal of Economic Behavior and Organization. Vol. 3, No. 2, 2015, pp. 23-28. doi: 10.11648/j.jjebo.20150302.12

\begin{abstract}
The paper investigated the causal relationship between IRAN underground economy and unemployment rate with Toda-Yamamoto approach for annual data during the period 1973-2012. The size of the underground economy measured as official GDP is estimated using a Multiple indicator- Multiple Causes (MIMIC) approach. The size of the underground economy has been associated with increased over the four decades, However has fluctuations in the first two decades but shows quite ascending trend in the last two decades. The empirical results point out that there is strong evidence of unidirectional causality running from unemployment rate to underground economy.
\end{abstract}

Keywords: Underground Economy, Unemployment Rate, MIMIC Model, Toda-Yamamoto Approach

\section{Introduction}

Unemployment and attitude toward work in the underground economy is the major challenges of IRAN economy. the high unemployment rate in recent years caused the entering the active force in the underground economy. underground economy can be defined as a sum of economic activaty that may legal or illegal but can not be measured and report. A growing underground economy has an impact on the formal sector through its effect on the product, money and labour markets. In the product market, an increasing underground economy activate persuasions the flow of inputs out of the formal sector which can depress productivity in the formal sector. Secondly, most transactions in the underground economy are carried out in cash. This raises the demand for currency. Finally, an increase in the unemployment rate reduces the proportion of workers employed in the formal sector. Consequently this leads to higher labour participation rates in the underground economy. This paper aims to estimate the size of the IRAN underground economy and examim the causality relationship between the underground economy (UE) and the unemployment rate (UR) in the IRAN. Therefore first, estimate the size of the underground economy using the multiple indicator multiple cause model (MIMC). Secondly, employs the Granger causality tests to investigate long-run relationship and the direction of causality between the underground economy (UE) and the unemployment rate
(UR). This paper is divided into five sections. Section 2 provides an overview of the underground economy and the link between the underground economy and unemployment. Section. 3 presents how the underground economy is estimated using the Multiple Indicators Multiple Causes Model (MIMIC).section 4 Examined the relationship between underground economy and the unemployment rate. section 5 is the conclusion.

\section{An Review on the Underground Economy and Its Relationship to Unemployment}

In this section, present an overview on the underground economy. we also didiscuss the connection between the underground economy and the unemployment rate.

\subsection{An Overview on the Underground Economy}

In the literature, underground economy is also called parallel, unofficial, shadow, black and irregular economy. There is also no agreement on the definition of the underground economy and on its measurement approaches as it has many different names. Therefore, there are many definitions for the underground economy and its measurement approaches. One of the One commonly used definition is: all currently unregistered economic activitie 
swhich contribute to the officially calculated Gross National Product $^{1}$. Smith (1994) defines it as, market based production of goods and services, whether legal or illegal, that escapes detection in the official estimates of gross domestic product. used diffrent ways to estimate underground economy that They can be classified into two general categories, including: direct approach and indirect approach direct approach, These approaches are also called micro approaches since they use well-designed surveys and samples based on voluntary replies or tax auditing.

Indirect approach, indirect approaches are macroeconomic approaches. These approaches are also called indicator approaches since they use many economic indicators that give information about development of underground economy over time. diffrent ways that used in indirect approach consist of Use of National Accounts, The difference between actual and formal labor, transaction approach , approach to money demand, Methods of physical data and MIMIC approach.

\subsection{Overview of the Relationship Between the Underground Economy and Unemployment Rate}

Underground economy Considered as an alternative source of employment for workers that limited to employed in official economy. Workers who work in the underground part Do not receive any social services or insurance But these workers prefer working in the underground economy instead of being unemployed and having no income. Also suggest that the working in the underground economy might be a transitory situation for workers who are waiting to find jobs in the underground ecnomy. Schneider and Enste (2000) discussion that the individual decision to work in the underground economy is the reply to being overburdened by tax and state regulations. Increased tax bills, social pressures And increased provisions for employing labor in the formal sector of the economy not only Reduced economic activity It provides propensity for employment in the underground economy. also these rigours Increases the cost of production in the formal economy than underground economy . some of the country use of polices for reduce unemployment rate for example France and Germany reduced working hours because of the limited amount of work But Enste (2003) discussion that this policy "neglects" the fact that reducing the number of hours of work below worker's preferences raises the quantity of hours worked in the underground economy. This increases the growth of the underground economy. Early retirement also increases the quantity of hours worked in the underground economy.

In Italy, Bertola and Garibaldi (2003) ptovide the case that an increase in payroll taxation can have effect on the supply of labour and the size of the underground economy. Work in underground economic activity is not limited only to the unemployed labour but workers who work in the official economy may also work part-time employment in the

1. This definition is used for example, by Feige $(1989,1994)$, Schneider (1994a, 2005a, 2005b), Frey and Pommerehne (1984), and Lubell (1991). underground economy because provided possible to work as part time on the underground system. (shnider and Ents 2000).

\section{Modelling the Underground Economy}

In this section, we show how the underground economy is modeled. We modeled the underground economy using the Multiple indicator- Multiple Causes model(MIMIC). is a special case of structural equation model that measure the latent variable. This model includes several causal variables as causes of the underground economy and Some index as a indicator of underground economy and a latent variable is underground economy. The model established based on two equation that shown in below:

$$
\begin{gathered}
y=\lambda \eta+\varepsilon \\
\eta=\Upsilon X+v
\end{gathered}
$$

The first equaition is a measurement equaition that links indicators with the latent variable, in these equaition, two equaition is a structural equaition that that captures the relationships among the latent variable and the causes

$\eta$ is the scalar latent variable(the size of underground economy)

$\mathrm{y}$ is a vector of indicators of the latent variable,

$X=(X 1, \ldots X q)$ is the vector of causes of underground economy

$\lambda(p .1)$ and $\Upsilon(q .1)$ vectors of parameters

Substituting equation 1 and 2 yields a reduced form solution which expresses a relationship betweenthe observed variables $x_{t}$ and $y_{t}$ This is shown in equation 3 :

$$
y_{t}=\pi x_{t}+z_{\mathrm{t}}
$$

$\pi=\lambda \gamma$ is a reduced form coefficients matrix and has rank one

$z_{t}=\lambda v_{t}+\varepsilon_{t}:$ is a reduced form disturbance vector;

This system of equations is faced with the problem of identifying To avoid this problem an elements of $\lambda$ bound to the Pre-determined amount ${ }^{2}$.

The variables used in this study as the caus es of the underground economy consist of: Trade restrictions $\left(\mathrm{X}_{1}\right)$, Unemployment $\left(\mathrm{X}_{2}\right)$, Inflaition $\left(\mathrm{X}_{3}\right)$, Direct tax burden $\left(\mathrm{X}_{4}\right)$, Growth tax burden $\left(\mathrm{X}_{5}\right)$, Government size $\left(\mathrm{X}_{6}\right)$ and Per capita income $\left(\mathrm{X}_{7}\right)$. The indicator variables incorporated in the model are: real gross domestic product index $\left(Y_{1}\right)$, Energy consumption $\left(\mathrm{Y}_{2}\right)$, Cash demand $\left(\mathrm{Y}_{3}\right)$.

\subsection{Data Issues}

In this section we discuss the data used for the estimation. The data series are Annual from 1973 to 2012. The series in levels or differences have been tested for unit root. This is shown in Appendix (1). We use the Augmented-Dicky Fuller

1. For details about the effects of normalization on structural coefficients, see Dell'Anno,

Gomez and Alañón (2007). 
(ADF) test and Phillips-Perron (PP) test.

\subsection{Estimating the IRAN Underground Economy White the MIMIC Model}

In this part we discuss how the model is estimated using the MIMIC model.frist, we estimate several specifications of the models. We test for identification and then proceed to discuss the sign and significance of the estimated coefficients as well as the Goodness of Fit of our model. In estimating the size of underground economy, the latant variable is modelled as a linear function of a set of exogenous variable that shown in equation (4):

$$
\eta_{\mathrm{t}}=Y_{1} \mathrm{X}_{1 \mathrm{t}}+Y_{2} X_{2 \mathrm{t}}+Y_{3} X_{3 \mathrm{t}}+Y_{4} X_{4} \mathrm{t}+Y_{5} X_{5 \mathrm{t}}+Y_{6} X_{6 \mathrm{t}}+Y_{7} X_{7 \mathrm{t}}+\zeta_{\tau}
$$

Several model specifications are considered. These are shown in Appendix (2). We then compare the fitted models and selected MIMIC $7-1-3$ as the best model of iran underground economy. The model has 3 indicators and 7 causal factors. The coefficient of the index of real GDP is normalized to 1 to sufficiently identify the model. The estimates of the equation (4) that extracted by MIMIC 7-1-3, are used to obtain an ordinal time series index for underground economy ${ }^{3}$.calculated the series of underground economy as the ranking index Using the estimated values of $\Upsilon$ and amount of causal variable during the period Research . the obtained ordinal series needs to be converted to a cardinal series. This can be done by scaling the available ordinal series using 'benchmark estimates' from other studies or by estimating a cardinal series through some other approach and using values from it to calibrate the ordinal series obtained by the MIMIC approach(Schneider and Enste 2000). In thist paper we used the first option and year of 1987 select as the benchmark estimate. The year selected is 1987 because this is the year in which there are several estimates of the iran underground economy. This is shown in table 1.average these studies used as benchmark estimates to convert ordinal series to cardinal series.

Table 1. Estimates of the size of iran undergroundeconomy (1987).

\begin{tabular}{lll}
\hline Author & Method & $\begin{array}{l}\text { Size of underground } \\
\text { economy }\end{array}$ \\
\hline $\begin{array}{l}\text { Khalatbari. F } \\
\text { Ashrafzade and }\end{array}$ & Currency demand & $11 \%$ \\
Mehregan & Money demand & $15 \%$ \\
Arabmazar.Ali & MIMIC approch & $13 \%$ \\
\hline
\end{tabular}

Means for 1988: $13 \%$

The index is scaled to take up to a value of $13 \%$ in 1987 and Obtained size of underground economy for other years Through The following operations:

$$
\eta_{t}=\eta_{t} * \frac{\eta 1987}{\eta * 1987}
$$

$\eta_{\mathrm{t}}:$ is amount of underground cconomy as a percentage of

1. For a fuller treatment of this subject, we refer the reader to Dell'Anno and Schneider (2006). official GDP.

$\eta_{\mathrm{t}}{ }^{*}$ :is the index of underground economy calculated by (4) as a percentage of official GDP.

$\eta 1987: 13 \%$ is the exogenous estimate of underground economy;

$\eta *_{1987}$ : is the value of index estimated by (4)

In Figure 1, the rezult of MIMIC 7-1-3 are shown for the period 1973 to 2012 The underground economy measured as percentage of official GDP

The underground economy measured as percentage of official GDP records the value of $5.8 \%$ in the 1973 and $36 \%$ in the 2012. The size of the underground economy has been associated with increased over the four decades, However has fluctuationsin the first two decades but shows quite ascending trend in the last two decades.

\section{Is There a Structural Link between the Underground Economy and Unemployment Rate}

After we estimate the size of the underground economy, we investigate the nature of the causality relationship between the two variables using Toda-Yamamoto approach.

Toda and Yamamoto (1995) causality test is applied in level VARs irrespective of whether the variables are integrated, cointegrated, or not. Toda and Yamamoto argue that F-statistic used to test for traditional Granger causality may not be valid as the test does not have a standard distribution when the time series data integrated or cointegrated .The Toda-Yamamoto procedure basically involves estimation of an augmented VAR $(k+d \max )$ model, where $k$ is the optimal lag length in the original VAR system and $d$ max is maximal order of integration of the variables in the VAR system. This test done in tow stage. The first stage determines the optimal lag length $(k)$ and the maximum order of integration $(d)$ of the variables in the system.

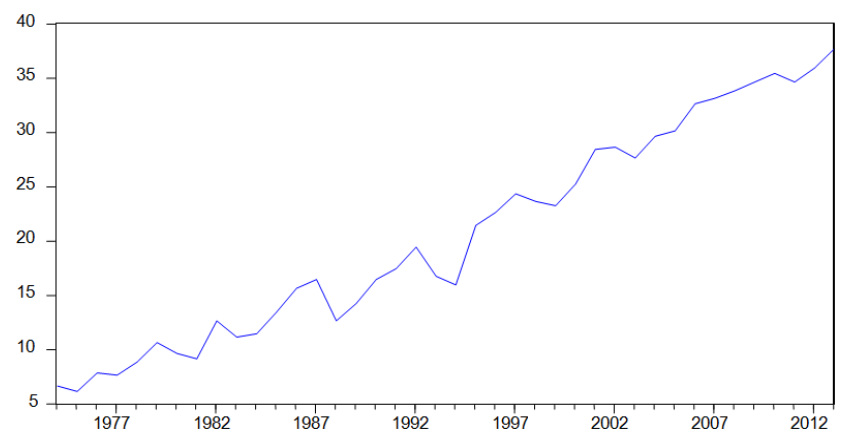

Figure 1. Shadow economy as percentage of official GDP.

The lag length, $k$ is generated in the process of the VAR in levels among the variables in the system by using different lag length criterion such as AIC or SBC . the order of integration, $d$ Identified by used of the unite root test such as ADF and Phillips-Perron tests. The second stage uses the modified Wald procedure to test the VAR $(k)$ model for causality. The optimal lag length is equal to $p=[k+d(\max )]$. 
In the case of a bivariate $(Y, X)$ relationship, Toda and Yamamoto causality test is demonstrated as follows:

$$
\begin{aligned}
\mathrm{Y}_{\mathrm{t}}= & a_{0}+\sum_{i=1}^{k} b_{1 i} \cdot Y_{t-i}+\sum_{i=k+1}^{k+d m a x} b_{2 i} \cdot Y_{t-i}+ \\
& \sum_{i=1}^{k} c_{1 i} \cdot x_{t-i}+\sum_{i=k+1}^{k+d m a x} c_{2 i} \cdot x_{t-i}+e_{1 t} \\
= & d_{0}+\sum_{i=1}^{k} e_{1 i} \cdot x_{t-i}+\sum_{i=k+1}^{k+d m a x} e_{2 i} \cdot x_{t-i}+ \\
& \sum_{i=1}^{k} f_{1 i} \cdot Y_{t-i}+\sum_{i=k+1}^{k+d m a x} f_{2 i} \cdot Y_{t-i}+e_{2 t} x_{\mathrm{t}}
\end{aligned}
$$

Where; $\mathrm{Y}_{\mathrm{t}}=\mathrm{UE}_{\mathrm{t}}, x_{\mathrm{t}}=\mathrm{UR}_{\mathrm{t}} e_{1 t}, e_{2 t}$ are the residuals of the models.
The null hypothesis that $X$ does not cause $Y$ is constructed as follows; $\mathrm{H}_{0}=\mathrm{C}_{1 \mathrm{i}}=0$,

$\mathrm{i}=1, \ldots \ldots, \mathrm{k}$. the alternaitive null hypothesis that $Y$ does not cause $X$ is formulated as follows:

$\mathrm{H}_{0}=\mathrm{f}_{1 \mathrm{i}}=0, \mathrm{i}=1, \ldots ., \mathrm{k}$

We employed the Augmented Dickey-Fuller (ADF) and Phillips-Peron (PP) tests to examine the integrating order of the variables under consideration. The results of the unit root

\begin{tabular}{|c|c|c|c|c|c|c|c|}
\hline & & \multicolumn{3}{|c|}{ UE(Undergroundeconomy) } & \multicolumn{3}{|c|}{ UR(Unemployment rate) } \\
\hline & & T\&C & $\mathbf{C}$ & None & T\&C & $\mathbf{C}$ & None \\
\hline \multirow{2}{*}{ level } & $\mathrm{ADF}$ & -1.11 & -1.25 & -0.79 & -1.11 & -1.43 & -0.13 \\
\hline & $\mathrm{PP}$ & -2.05 & -1.28 & -0.79 & -1.31 & -1.67 & -0.28 \\
\hline \multirow{2}{*}{ Firist difference } & $\mathrm{ADF}$ & $-6.53 *$ & $-6.05^{*}$ & $-3.07 * *$ & $-4.45 *$ & $-4.89 *$ & $-4.05 *$ \\
\hline & PP & $-6.87 *$ & $-6.11 *$ & $-5.45^{*}$ & $-4.25 *$ & $-4.31 *$ & $-4.13 *$ \\
\hline
\end{tabular}
tests for the variables in their levels and first differences are reported in Table 2.

Table 2. Test of unit root hypothesis $H_{0}$ : One unit root; $H_{1}$ : No unit root.

Note: T\&C represents the most general model with a drift and trend; $\mathrm{C}$ is the model with a drift and without trend; None is the most restricted model without a drift and trend. *and ** denote rejection of the null hypothesis at the $1 \%$ and $5 \%$ levels respectively. Tests for unit roots have been carried out in E-VIEWS 7.0 .

Our results revealed that both the variables are I(1). Therefore, the maximum order of integration in the VAR system, $\mathrm{d}_{\max }=1$. Given that both series were found to be integrated of order one, we specify the bivariate VAR model by determining the optimal lag length of level variables in the model. Table 3 reports the optimal lag length. The optimum lag length $(\mathrm{k})$ chosen by AIC, SC, HQ the Toda-Yamamoto causality test results shown in Table III,
Table 3. Lag Length Selection.

\begin{tabular}{llll}
\hline Lag lenght & (HQ) & (SB) & (AIC) \\
\hline 1 & 6.34 & 6.51 & 6.25 \\
2 & $6.29^{*}$ & $6.47^{*}$ & $6.24^{*}$ \\
3 & 6.38 & 6.77 & 6.26 \\
\hline
\end{tabular}

*indicates lag order selected by the criterion

Table 4. Tado-Yamamoto Causality (Modified WALD) Test Results.

\begin{tabular}{llll}
\hline Null hypothesis & M Wald statistics & P values & Decision \\
\hline $\mathrm{H}_{0}$ : UR does not Granger cause UE & $15 / 51$ & $0 / 0004^{*}$ & Rerject $\mathrm{H}_{0}$ \\
$\mathrm{H} 0$ :UE does not Granger cause UR & $0 / 57$ & $0 / 247$ & Don't reject $\mathrm{H}_{0}$ \\
\hline
\end{tabular}

* indicates rejection of the null at the $1 \%$ level

According to the Toda-Yamamoto causality test results shown in Table III, there is strong evidence of causality running from unemployment rate to underground economy at the $\% 1$ level of significance. The results do not reveal causality from underground economy to unemployment rate. Therefore, we can conclude that there is a uni-directional causality from unemployment rate to underground economy.

\section{Conclusions}

The study has investigated the nature of the relationship between unemployment rate and the size of the IRAN underground economy for the period 1973-2012, using TodaYamamoto approach . underground economy measured as percentage of official GDP and estimated using the MIMIC model. The size of the underground economy has been associated with increased over the four decades, However during 70 and 80 decades associated with fluctuationsin and less inceased but reveal quite ascending trend in the last two decades.The empirical results point out that there is strong evidence of uni-directional causality running from unemployment rate to underground economy at the $\% 1$ level of significanc.

\section{Appendix 1. Analysis of Non-Stationarity}

In this appendix we display the tests employed to detect the order of integration in the time series. The pioneer in

\begin{tabular}{|c|c|c|c|c|c|c|c|}
\hline \multirow{2}{*}{ Variable } & \multirow{2}{*}{ Causes } & \multirow{2}{*}{$\begin{array}{l}\text { Incl. } \\
\text { Equat. }\end{array}$} & \multicolumn{2}{|l|}{ Level } & \multicolumn{2}{|c|}{ First difference } & \multirow{2}{*}{$\begin{array}{l}\text { Unit root } \\
\text { analysis }\end{array}$} \\
\hline & & & ADF & $\mathbf{P P}$ & ADF & PP & \\
\hline \multirow{3}{*}{$\mathrm{X}_{1}$} & \multirow{3}{*}{ Trade restrictions } & $\mathrm{T} \& \mathrm{C}$ & -1.26 & -2.03 & $-3.61^{*}$ & $-5.12 *$ & \multirow{3}{*}{$\mathrm{I}(1)$} \\
\hline & & $\mathrm{C}$ & -1.32 & -2.21 & $-3.74 *$ & $-5.23^{*}$ & \\
\hline & & None & -1.02 & -2.13 & $-3.49 *$ & $-5.07 *$ & \\
\hline
\end{tabular}
tackling the problem of non-stationarity in the MIMIC models has been Giles (1995).

Table 5. Unit root analysis. 


\begin{tabular}{|c|c|c|c|c|c|c|c|}
\hline \multirow{2}{*}{ Variable } & \multirow{2}{*}{ Causes } & \multirow{2}{*}{$\begin{array}{l}\text { Incl. } \\
\text { Equat. }\end{array}$} & \multirow{2}{*}{$\begin{array}{l}\text { Level } \\
\text { ADF }\end{array}$} & \multicolumn{3}{|c|}{ First difference } & \multirow{2}{*}{$\begin{array}{l}\text { Unit root } \\
\text { analysis }\end{array}$} \\
\hline & & & & PP & ADF & PP & \\
\hline \multirow{4}{*}{$\mathrm{X}_{2}$} & \multirow{3}{*}{ Unemployment Rate } & $\mathrm{T} \& \mathrm{C}$ & -1.44 & -1.39 & $-3.63 *$ & $-4.32 *$ & \multirow{3}{*}{$\mathrm{I}(1)$} \\
\hline & & $\mathrm{C}$ & -1.62 & -1.42 & $-3.98^{*}$ & -4.39 & \\
\hline & & None & -1.11 & -1.36 & $-3.42 *$ & $-4.16^{*}$ & \\
\hline & & $\mathrm{T} \& \mathrm{C}$ & -0.96 & -1.12 & $-4.74 *$ & $-5.23 *$ & \\
\hline \multirow[t]{3}{*}{$\mathrm{X}_{3}$} & \multirow[t]{3}{*}{ Inflaition } & $\mathrm{C}$ & -0.85 & -1.26 & $-4.56^{*}$ & $-5.56^{*}$ & \multirow[t]{3}{*}{$\mathrm{I}(1)$} \\
\hline & & None & -1.06 & -0.94 & $-4.12 *$ & $-5.32 *$ & \\
\hline & & $\mathrm{T} \& \mathrm{C}$ & -1.87 & -1.65 & $-5.36 *$ & $-6.23 *$ & \\
\hline \multirow[t]{3}{*}{$\mathrm{X}_{4}$} & \multirow[t]{3}{*}{ Direct tax burden } & $\mathrm{C}$ & -1.69 & -1.47 & $-5.79 *$ & $-6.29 *$ & \multirow[t]{3}{*}{$\mathrm{I}(1)$} \\
\hline & & None & -1.14 & -1.26 & $-5.31 *$ & $-6.13 *$ & \\
\hline & & $\mathrm{T} \& \mathrm{C}$ & $-3.96 *$ & $-3.65 *$ & & & \\
\hline \multirow[t]{3}{*}{$\mathrm{X}_{5}$} & \multirow{3}{*}{ Growth tax burden } & $\mathrm{C}$ & $-3.87 *$ & $-3.44 *$ & & & \multirow{3}{*}{$\mathrm{I}(0)$} \\
\hline & & None & $-3.25 *$ & $-3.12 *$ & & & \\
\hline & & $\mathrm{T} \& \mathrm{C}$ & -0.45 & -1.09 & $-3.21 *$ & $-4.23 *$ & \\
\hline \multirow[t]{3}{*}{$\mathrm{X}_{6}$} & \multirow{3}{*}{ Government size } & $\mathrm{C}$ & -0.59 & -1.12 & $-3.41 *$ & $-4.41 *$ & \multirow[t]{3}{*}{$\mathrm{I}(1)$} \\
\hline & & None & -0.12 & -1.06 & $-3.06^{*}$ & $-4.13^{*}$ & \\
\hline & & $\mathrm{T} \& \mathrm{C}$ & -1.23 & -1.41 & $-3.67 *$ & $-4.13 *$ & \\
\hline \multirow[t]{2}{*}{$\mathrm{X}_{7}$} & \multirow[t]{2}{*}{ Per capita income } & $\mathrm{C}$ & -1.29 & -1.38 & $-3.56^{*}$ & $-4.22 *$ & \multirow[t]{2}{*}{$\mathrm{I}(1)$} \\
\hline & & None & -1.11 & -1.16 & $-3.41 *$ & $-4.11 *$ & \\
\hline \multicolumn{8}{|l|}{ Indicators } \\
\hline & & $\mathrm{T} \& \mathrm{C}$ & -1.32 & -1.88 & $-5.61 *$ & $-5.77 *$ & \\
\hline \multirow[t]{3}{*}{$\mathrm{Y}_{1}$} & \multirow[t]{3}{*}{ real gross domestic product } & $\mathrm{C}$ & -1.69 & -1.96 & $-5.99 *$ & $-5.23 *$ & \multirow[t]{3}{*}{$\mathrm{I}(1)$} \\
\hline & & None & -1.13 & -1.63 & $-5.23 *$ & $-5.62 *$ & \\
\hline & & $\mathrm{T} \& \mathrm{C}$ & -1.62 & -2.01 & $-5.32 *$ & $-6.64 *$ & \\
\hline \multirow[t]{3}{*}{$\mathrm{Y}_{2}$} & \multirow[t]{3}{*}{ Energy consumption } & $\mathrm{C}$ & -1.55 & -1.68 & $-5.74 *$ & $-6.38 *$ & $\mathrm{I}(1)$ \\
\hline & & None & -1.20 & -1.72 & $-5.36^{*}$ & $-6.41 *$ & \\
\hline & & $\mathrm{T} \& \mathrm{C}$ & -0.62 & -1.01 & $-3.68 *$ & $-4.12 *$ & \\
\hline$Y_{3}$ & Cash demand & $\mathrm{C}$ & -0.71 & -0.84 & $-3.47 *$ & $-4.21 *$ & $\mathrm{I}(1)$ \\
\hline & & None & -0.33 & -1.10 & $-3.32 *$ & $-4.32 *$ & \\
\hline
\end{tabular}

Note:T\&C represents the model with a drift and trend; $\mathrm{C}$ is the model with a drift and without trend; None is the most restricted model without a drift and trend. * denote rejection of the null hypothesis at the $5 \%$ levels respectively.

\section{Appendix 2. Result Estimated Coefficients of the MIMIC Models}

Table 1. Estimated Coefficients of the MIMIC Models and descriptive statistics.

\begin{tabular}{|c|c|c|c|c|c|}
\hline Causal variables & \begin{tabular}{|ll} 
Models & $\left.\begin{array}{l}\text { MIMIC } \\
(6-1-3\end{array}\right)$ \\
\end{tabular} & $\begin{array}{l}\text { MIMIC } \\
(7-1-3 \text { a) } \\
\end{array}$ & $\begin{array}{l}\text { MIMIC } \\
(6-1-3 \text { b) } \\
\end{array}$ & $\begin{array}{l}\text { MIMIC } \\
(7-1-3 \text { b) } \\
\end{array}$ & $\begin{array}{l}\text { MIMIC } \\
(5-1-3)\end{array}$ \\
\hline Trade restrictions & $\begin{array}{l}0.05 \\
(0.84)\end{array}$ & $\begin{array}{l}0.11^{*} \\
(2.02)\end{array}$ & $\begin{array}{l}0.11^{*} \\
(2.21)\end{array}$ & $\begin{array}{l}0.05 \\
(1.39)\end{array}$ & $\begin{array}{l}0.08^{*} \\
(2.16)\end{array}$ \\
\hline Unemployment Rate & $\begin{array}{l}0.10 \\
(1.12)\end{array}$ & $\begin{array}{l}0.12^{*} \\
(2.21)\end{array}$ & $\begin{array}{l}0.10^{*} \\
(2.14)\end{array}$ & $\begin{array}{l}0.11 \\
(1.56)\end{array}$ & $\begin{array}{l}0.13^{*} \\
(2.51)\end{array}$ \\
\hline Inflaition & $\begin{array}{l}0.23 * \\
(2.45)\end{array}$ & $\begin{array}{l}0.14 * \\
(2.37)\end{array}$ & $\begin{array}{l}0.17 * \\
(2.51)\end{array}$ & $\begin{array}{l}0.19^{*} \\
(2.19)\end{array}$ & $\begin{array}{l}0.21 * \\
(2.25)\end{array}$ \\
\hline Direct tax burden & $\begin{array}{l}0.16^{*} \\
(2.35)\end{array}$ & $\begin{array}{l}0.1^{*} \\
(2.14)\end{array}$ & $\begin{array}{l}0.06 \\
(1.66)\end{array}$ & $\begin{array}{l}0.17^{*} \\
(2.45)\end{array}$ & \\
\hline Growth tax burden & & $\begin{array}{l}0.01 \\
(0.35)\end{array}$ & $\begin{array}{l}0.02 \\
(0.71)\end{array}$ & $\begin{array}{l}0.05 \\
(0.78)\end{array}$ & $\begin{array}{l}0.01 \\
(0.46)\end{array}$ \\
\hline Government size & $\begin{array}{l}0.04 \\
(0.73)\end{array}$ & $\begin{array}{l}0.5 \\
(1.52)\end{array}$ & - & $\begin{array}{l}0.08 \\
(1.31)\end{array}$ & - \\
\hline Per capita income & $\begin{array}{l}-0.09 \\
(-1.11)\end{array}$ & $\begin{array}{l}-0.06 \\
(-1.11)\end{array}$ & $\begin{array}{l}-0.07 \\
(-1.41)\end{array}$ & $\begin{array}{l}-0.17^{*} \\
(-2.52)\end{array}$ & $\begin{array}{l}-0.07 \\
(-0.91)\end{array}$ \\
\hline \multicolumn{6}{|l|}{ Indicators } \\
\hline real gross domestic product & 1 & 1 & 1 & $\begin{array}{l}0.87^{*} \\
(3.12)\end{array}$ & $\begin{array}{l}0.51^{*} \\
(7.45)\end{array}$ \\
\hline Energy consumption & $\begin{array}{l}1.45^{*} \\
(5.42)\end{array}$ & $\begin{array}{l}2.07^{*} \\
(5.13)\end{array}$ & $\begin{array}{l}1.96^{*} \\
(4.62)\end{array}$ & 1 & 1 \\
\hline Cash demand & $\begin{array}{l}5.80^{*} \\
(12.56)\end{array}$ & $\begin{array}{l}4.12 \\
(7.05)\end{array}$ & $\begin{array}{l}5.61^{*} \\
(7.63)\end{array}$ & $\begin{array}{l}3.2^{*} \\
(9.46)\end{array}$ & $\begin{array}{l}2.99 * \\
(11.64)\end{array}$ \\
\hline \multicolumn{6}{|l|}{ Statistical tests } \\
\hline $\mathrm{AGFI}^{1}$ & .91 & 96 & 95 & 90 & 94 \\
\hline RMSEA $^{2}$ & 0.021 & 0.011 & .041 & 0.051 & .032 \\
\hline Chi-square & 32.64 & 34.12 & 38.66 & 43.07 & 34.12 \\
\hline
\end{tabular}


Notes: t-statistic are given in parentheses. * Means |tstatistic $>1.96$. All variables are used as their standardized deviations from the mean. According to the MIMIC models identification rule, one indicator has to be fixed to an a priori value.

1. Adjusted Goodness of Fit Index.

2. Root Mean Square Error of Approximation

\section{References}

[1] Alexandru, A., Dobre, I., Ghinararu, C.(2010b).The relationship between unemployment rate and the size of the shadow economy. The case of United States, WSEAS Transactions on Business and Economics, issue 4, vol.7, pp.359-369.

[2] Arabmazar ,Ali (1982) .Black eeconomy in iran:size, causes and indicator in last three decade, journal of Program and Budget ,No 62 pp.3-62

[3] Bertola, G., Garibaldi, P. (2003). The Structure and History of Italian Unemployment, CESifo Working Papers, n.907.

[4] Boeri, T., Garibaldi, P. (2002). Shadow Activity and Unemployment in a Depressed Labor Market, CEPR Discussion papers, n.3433.

[5] Dell'Anno, Roberto, Miguel Gomez, and Angel Alañón Pardo (2007), "Shadow economy in three different Mediterranean countries: France, Spain and Greece. A MIMIC approach", Empirical Economics 33: 51-84.

[6] Dell'Anno, Roberto, and Friederich Schneider (2006), "Estimating the underground economy:A response to $T$. Breusch's critique", Working Paper 06/07, Department of Economics,Johannes Kepler University of Linz.

[7] Dickey, D., Fuller,W.A.(1981). Likelihood ratio statistics for autoregressive time series with a unit root, Econometrica, Vol. 49, 1981, pp. 1057-72.
[8] Enste, D.H.(2003). Shadow Economy and Institutional Change in Transition Countries in Boyan Belev (eds.), The Informal Economy in the EU Assessment Countries: Size, Scope, Trends and Challenges of the Process of EUenlargement, Center for Study of Democracy, 2003, Sofia, 81114.

[9] Giles, D.E.A.(1999).Modeling the hidden economy in the taxgap in New Zealand, Empirical Economics, vol.24, no.4/1999, pp.621-640.

[10] Jöreskog, K., Goldberger, A.S.(1975). Estimation of a model with multiple indicators and multiple causes of a single latent variable, Journal of the American Statistical Association, 70/1975, pp.631-639.

[11] Khalatbari, Firoze. (1980). Underground economy in iran,Ronagh jounal , No 1 ,PP.5-11.

[12] Lubell, H. (1991): The informal sector in the 1980's and 1990's, Paris: OECD

[13] Phillips, P.B., Perron, P.(1985). Testing for a unit root in time series regression, Biometrica, Vol. 75, 1985, pp. 335-346.

[14] Schneider.F, D.H., Enste (2000) Shadow economies: size, causes and consequences, Journal of Economic Literature 38, pp. 77-114

[15] Schneider, F.(2009). Shadow Economies and Corruption all over the world: New estimates for 145 Countries, Economics, 2009, pp. 1-47.

[16] Tedds . L (1998), Measuring the size of the hidden economy in Canada: a latent variable/MIMIC model approach. Unpublished M.A. Extended Essay, Department of Economics, University of Victoria

[17] Toda, H.Y., Yamamoto, H (1995) . Statistical inference in vector autoregressions with possibly integrated processes. Journal of Econometrics, Vol. 66/1995, pp. 225-250. 